\title{
A corpus separatum elszakadása a Magyar Királyságtól: Fiume 1918. november 4.
}

\author{
Hamerli Petra*
}

\begin{abstract}
Corpus separatum" tear away Hungarian Kingdom: Fiume, November 4, 1918. After the Great War, in autumn 1918 the nationalities of the AustroHungarian Monarchy proclaimed their independence. Croatia, which formed a personal union with the Hungarian Kingdom for centuries, was recognized to be an independent state by the Hungarian Government. The Croatian Committee formed in London in 1915 expressed its willing to be part of a federalist South-Slavic state. In this way Hungary lost its only one port, the city of Fiume, as territorically it was part of the Istria. Nevertheless, it was not obvious that Croatia could keep Fiume - Rijeka -, as the Italian National Council of the city formed on 30 October 1918 proclaimed its belonging to Italy through a petition written on 4 November 1918 to the prime minister Vittorio Emanuele Orlando, as the majority of the Fiumean citizens were Italians. This petition made Italy to claim Fiume on the Paris Peace Conference held in 1919, although it was not judged or promised to the Italians in the secret Treaty of London of 1915 that made Italy to enter into the war. The question of Fiume caused serious conflict among Italy and Yugoslavia, and - as the Peace Conference gave the city to the Yugoslavian Kingdom - in autumn 1919 the Italian poet Gabriele D'Annunzio decided to annex Fiume and create a city state. In my paper I will present, through the case of Fiume, what consequences an only day - in this case the 4 November 1918 - can have in history.
\end{abstract}

Keywords: $\quad$ Great War (1914-1918), history of Central-Europe, History of Hungarian Kingdom, Fiume (Rijeka)

1918. október 30-án megalakult a Fiumei Olasz Nemzeti Tanács, amely kinyilvánította a város Olaszországhoz történő csatlakozását. A szóbeli közlést november 4-én hivatalos petíció erősítette meg, amelyet a Tanács képviselői Vittorio Emanuele Orlando olasz miniszterelnöknek nyújtottak át. Tekintve, hogy Fiuméra az alakulóban lévő Szerb-Horvát-Szlovén Királyság - Jugoszlávia ${ }^{1}$ - is igényt tartott, a város birtoklásának kérdése komoly konfliktust eredményezett az olaszok és a jugoszlávok között az 1919 januárjában kezdődő párizsi békekonferencián, amelynek során a felek igyekeztek hathatós érveket felsorakoztatni saját álláspontjuk mellett. Az olasz delegátusok a

\footnotetext{
* Intézmény: Pécsi Tudományegyetem Bölcsészettudományi Kar Email: hamerli.petra@gmail.com

${ }^{1}$ Bár a délszláv állam 1929 előtt hivatalosan a Szerb-Horvát-Szlovén Királyság nevet viselte, a korabeli források és a szakirodalom egyaránt többnyire a „Jugoszlávia” elnevezést alkalmazza ezekre az esztendőkre vonatkozóan is. Ennek megfelelően írásomban én is ezt a tendenciát követem.
} 
Thomas Woodrow Wilson amerikai elnök által, 1918 januárjában nyilvánosságra hozott 14 pontban foglalt nemzeti önrendelkezési jogra, a jugoszlávok pedig gazdaságistratégiai tényezőkre alapozták érveiket. Mivel utóbb a békekonferencia Jugoszláviának ítélte a kikötővárost, Gabriele D’Annunzio olasz költő 1919. szeptember 12-én önkénteseivel - Fiumei Légió - bevonult a városba, ahol megalapította a Quarnarói Olasz Régensség elnevezésü államalakulatot. ${ }^{2}$

Tanulmányomban azt a napot - annak előzményeivel és következményeivel együtt - kívánom bemutatni, amikor a Fiumei Olasz Nemzeti Tanács kinyilvánította szándékát, megalapozva ezzel a későbbi konfliktusokat és a városállam megalapítását.

\section{Fiume az Osztrák-Magyar Monarchia felbomlása előtt}

Az Európa térképét átrajzoló első világháború utolsó hónapjaira nyilvánvalóvá vált, hogy egyik korábbi, soknemzetiségü volta miatt meglehetősen ingatag lábakon álló állama, a dualista Osztrák-Magyar Monarchia a háborút követően fel fog bomlani. 1918 őszére ugyanis az antanthatalmak és szövetségeseik úgy vélekedtek, hogy a nemzetiségi konfliktusokkal terhelt birodalom fennmaradása esetén sem lenne többé képes betölteni az európai erőegyensúlyban játszott korábbi szerepét, ezért az antant kormányok a szláv nemzetiségek elszakadási törekvéseit támogatták. ${ }^{3}$ Ez nyilvánvalóan maga után vonta, hogy a birodalom mindkét pillérének, azaz Ausztriának és Magyarországnak egyaránt számolnia kell területi veszteségekkel. Hogy némi engedményt tegyen, a magyar kormányzat elismerte a vele perszonálunióban lévő Horvátország függetlenségét, amelynek vezetői addigra a szerb vezetésű délszláv államhoz történő csatlakozás mellett határozták el magukat. Ebben a helyzetben egyértelművé vált, hogy az egyetlen magyar kikötőváros, Fiume - amelynek hátországa Horvátország részét képezte - ugyancsak nem maradhat meg magyar kézen.

Ami Fiume Magyarországon, és később a Monarchián belüli helyzetét jelenti, a város a felvilágosodás idején kibontakozó nemesi ellenállás alatt jutott először meghatározó szerephez, ami kereskedelmi és gazdasági lehetőségeinek volt köszönhető. ${ }^{4}$ A kikötőváros ugyanis jelentős szerepet töltött be a Nyugat-Európa, Budapest, Prága, Belgrád, valamint Zágráb között folyó kereskedelem bonyolításában. ${ }^{5}$

Vélhetően ez a jelentőség is hozzájárult ahhoz, hogy a horvát-magyar kiegyezés értelmében Fiume 1868 és 1918 között speciális helyzettel bírt az államon belül:

„Mindazon terület, mely jelenleg Buccari városával és kerületével együtt Fiume vármegyéhez tartozik, Fiume város és kerülete kivételével, a mely város, kikötö és kerület a magyar koronához csatolt külön testet (separatum sacrae regni coronae adnexum corpus) képez, s a melynek, mint ilyennek, külön autonomiájára (sic) s erre vonatkozó törvényhozási és kormányzati viszonyaira nézve, Magyarország országgyülése (sic) s Horvát-, Szlavon-és Dalmátországok országgyülése (sic) és Fiume városa közt, küldöttségi tárgyalások utján (sic), közös egyetértéssel lesz megállapodás eszközlendö."

\footnotetext{
${ }^{2}$ Gulyás László-Bali Lóránt 2011, 143-150.; Gulyás László-Bali Lóránt 2012/b, 41-53.

${ }^{3}$ Gulyás László-Szávai Ferenc 2018, 46-51.

${ }^{4}$ Mák Ferenc 2010, 14.

${ }^{5}$ Ledeen, Michael A. 1975, 31.

${ }^{6}$ http://www.1000ev.hu/index.php?a=3\&param=5352 (Utolsó letöltés: 2018. június 26.) A latin kifejezés rövid elnevezése ,corpus separatum”.
} 
Vagyis a város és kerülete autonómiával rendelkezett, de a magyar koronához kapcsolódott. Ez a döntés a magyar parlament, a horvát Sabor és Fiume városának egyetértésén alapult, és a jövőben is így hozták a Fiuméra vonatkozó rendelkezéseket. A „,corpus separatum”-státusz 1870. július 28 -án emelkedett törvényeröre. ${ }^{7}$ Az autonóm terület hivatalos nyelve az olasz volt, élén pedig a ,fiumei és magyar-horvát tengerparti királyi kormányzó" állt, akit a miniszterelnök előterjesztése nyomán a király nevezett ki. ${ }^{8}$ Magyar fennhatóság alatt állva a város olyan nagyfokú önállóságot élvezett, amit a horvát uralom minden bizonnyal nem tett volna számára lehetővé. ${ }^{9}$

Ami a város etnikai viszonyait illeti, Fiume olasz többségű település volt. Népességét olaszok, délszlávok (horvátok és szerbek), magyarok, szlovének (és vendek), valamint németek alkották. 1880 és 1910 között az olaszok száma egyenletesen és folyamatosan emelkedett, míg a horvát és szerb lakosság aránya csökkent. A magyar lakosok száma a fejlődés következtében nőtt, a szlovének és a németek aránya pedig 4\% körül mozgott. ${ }^{10} \mathrm{Az}$ 1910-es népszámlálás szerint a kikötőváros 50 ezer lakosából 27 ezren olaszok, 12 ezren horvátok, 6394-en pedig magyarok voltak. ${ }^{11}$ Utóbbiak száma 1914-re 10737 före emelkedett, vélhetően a város belső fejlődésének köszönhető bevándorlás miatt. ${ }^{12}$ Fiume 1869 és 1881 között rendkívüli gazdasági fejlődésnek indult. A kikötő forgalma hétszeresére nőtt, és a munkások sokkal jobb körülmények között éltek itt, mint általában a korabeli városokban. ${ }^{13}$ Hajógyár, torpedógyár, valamint dohánygyár biztosított munkahelyet az ide költözőknek. ${ }^{14}$

Ezt az idilli képet a folyamatos nemzetiségi ellentétek árnyékolták be. ${ }^{15} \mathrm{~A}$ feszültséget okozó helyzetek közül megemlítendő, hogy 1861. április 12-én az iskolákban kötelezővé tették a horvát nyelvoktatást, miután a horvátok közigazgatásilag többségbe kerültek. Ezt az olaszok úgy értékelték, hogy a horvátok nem tartják tiszteletben az olasz nyelvet. Ez évben a fiumeiek nem is küldtek képviselőt a horvát Saborba, négy évvel később pedig, amikor szóba került, hogy Fiumét esetleg Horvátországhoz csatolnák, a város delegáltjai tiltakozásukat fejezték ki ez ellen. ${ }^{16}$

Ennek fényében elmondható, hogy már az 1860-as években érezni lehetett az előszelét annak az olasz-horvát ellentétnek, amely az első világháború után, és különösen a békekonferencia alatt fokozódott.

\section{8. november 4.}

Miután a Horvátok, Szerbek és Szlovének Nemzeti Tanácsa 1918. október 29-én kimondta a Monarchiától való függetlenségét, a horvát katonaság megszállta a fiumei kormányzóság épületét, $\mathrm{s}$ úgy tủnt, hogy a város biztosan a délszláv állam részévé válik majd. ${ }^{17}$ Másnap, október 30-án azonban megalakult a Fiumei Olasz Nemzeti Tanács,

\footnotetext{
${ }^{7}$ Sonnino, Sidney 1972, 330.

${ }^{8}$ Romsics Ignác 2010, 23.

${ }^{9}$ Ledeen, Michael A. 1975, 31.

${ }^{10}$ Mák Ferenc 2010, 26.

${ }^{11}$ Ablonczy Balázs 2011, 240.

${ }^{12}$ Ablonczy Balázs 2011, uo.

${ }^{13}$ Ledeen, Michael A. 1975, 35.

${ }^{14}$ Ablonczy Balázs 2011, 240.

${ }^{15}$ Ablonczy Balázs 2011, 241.

${ }^{16}$ Mák Ferenc 2010, 21.

${ }^{17}$ Macmillan, Margaret 2005, 158.
} 
amely szóban kimondta a város Olaszországhoz tartozását, és polgármesterré választották a helyi olasz képviselőt, Antonio Viót. ${ }^{18}$

A szóbeli bejelentést 1918. november 4-én petíció követte, amelyben a Tanács kifejtette Vittorio Emanuele Orlando olasz miniszterelnöknek, hogy Fiume, Wilson elveinek megfelelően, az olasz többségre hivatkozva Olaszországhoz, mint anyaországhoz kíván csatlakozni: „, A Fiumei Olasz Nemzeti Tanács, mely a mai napon plenáris ülésen gyült egybe, kijelenti, hogy azon elv alapján, melynek értelmében minden népnek megadatik a nemzeti függetlenség joga, kinyilvánítja Fiume városának szabadságát. A város, mely eddig olasz jellegü külön test volt, magáévá teszi a nemzetek önrendelkezési jogának elvét. Ezen jogon alapulva a Nemzeti Tanács kijelenti Fiume csatlakozását az Anyaországhoz, az Olasz Királysághoz. A Fiumei Olasz Nemzeti Tanács, Fiume, 1918. október 30."19

Orlando úgy kommentálta a képviselők érkezését, hogy Fiume olaszsága kétségtelen annak ellenére, hogy a város nem szerepelt a londoni szerződés ígéretei között. A városnak az olasz anyaországhoz való csatlakozását a miniszterelnök a wilsoni elvekben megfogalmazott önrendelkezési joggal is megindokolhatónak tartotta. ${ }^{20} \mathrm{~A}$ külügyminiszter, Sidney Sonnino úgy vélekedett, hogy a delegáció ilyen kérése veszélyes, hiszen Olaszország nem kompromittálhatja magát olyan területek igénylésével, amiket az Olaszország antanthatalommá válását előidéző szerződés nem tartalmazott. ${ }^{21}$ Ennek ellenére, amikor a békekonferencián napirendre tüzték Fiume kérdését, a jelenlévő olasz delegátusok, így Sonnino is, egyöntetűen a város Olaszországhoz történő csatolása érdekében.

A kikötőváros sorsának alakulását a magyar sajtó is figyelemmel kísérte. „Fiume közigazgatása ez idő szerint még a horvátok kezében van, de úgy látszik, nem igen lesz sokáig. A város olaszsága már megalakitotta az olasz nemzeti tanácsot. (...) Vio Antal $d r$. [Antonio Vio - H. P.] polgármester, a magyar országgyülés volt tagja, bocsánatot kért honfitársaitól, hogy eddig magyarbarátnak mutatkozott. Erre a képmutatásra mondotta - Fiume érdekében volt kénytelen. Az ülés végül határozatilag kimondta, hogy Fiume az olasz anyaországhoz csatlakozott. A pecsétet erre a határozatra az olasz flotta megjelenése ütötte. Hétfön, november hó 4-én, délelött 11 órakor egy-egy olasz. dreadnought [csatahajó-típus - H. P.] és torpedónaszád érkezett Fiume belső kikötőjébe. A közönség ellepte a mólókat, felvirágozta és viharosan ünnepelte az olasz tengerészeket. "22 - írta $A z$ Újság címü, a liberális polgárság körében rendkívül népszerü magyar napilap. Délután, amint arról a szintén polgári napilap, Az Est tudósított, mintegy húszezer fős olasz tömeg járta az utcákat, az olasz királyi család, a Savoyaidinasztia zászlaját lobogtatva. A házakra kitüzték az olasz nemzeti lobogót, és az ablakokba helyezték Riccardo Zanella fiumei kormányzó babérkoszorúval szegélyezett arcképét. $^{23}$

Noha november 4-én a petíció átnyújtásán és az olasz lakosság ünneplésén kívül semmi érdemleges nem történt, a nap eseményei komoly következményekkel jártak a későbbiekre nézve.

\footnotetext{
${ }^{18}$ Az Est. 1918. november 8. 8. old. „Egy hétig az elszakadt Fiuméban.”

${ }^{19}$ Gerini, Giuseppe 1938, 24. Saját fordítás (a továbbiakban is, minden szó szerint idézett irat).

${ }^{20}$ I documenti diplomatici italiani. Serie 6. Volume 1. A cura di Rodolfo Mosca. Libreria dello Stato. Roma. 134. irat.

${ }^{21}$ I documenti diplomatici italiani. Serie 6. Volume 1. A cura di Rodolfo Mosca. Libreria dello Stato. Roma. 37. és 152. irat.

${ }^{22}$ Az Újság. 1918. november 6.

${ }^{23}$ Az Est. 1918. november 8.
} 


\section{Kié lesz Fiume?}

1919 januárjában Georges Clemenceau francia elnök vezetése alatt kezdetét vette a békekonferencia, amelynek Párizs adott otthont. Az eseményen az antanthatalmak - az átalakuló Oroszország kivételével - mellett a szövetségeseik és az úgynevezett társult hatalmak, azaz a Monarchia nemzetiségeinek képviselői vehettek részt. Az üléseken az utódállamok delegátusai kifejthették területi követeléseiket és a mellettük szóló érveket, amelyek alapján a békekonferencia Jugoszláviának ítélte Fiume városát.

A döntést Olaszország-szerte felháborodással fogadták, aminek megértéséhez szükséges röviden utalni arra, hogy Fiume milyen szerepet töltött be az olasz külpolitikában. Az első világháború kirobbanásakor Olaszország a semlegesség mellett foglalt állást, ám az 1915. április 26-án Angliával, Franciaországgal és az ekkor még szövetséges Oroszországgal aláírt londoni szerződés területi ígéretei rávették az antanthoz való csatlakozásra és a háborúba történő belépésre. A megállapodás értelmében Olaszország Trentino (Dél-Tirol) tartományt, Triesztet, a dalmát partvidék olasz lakta városait, a Brenner-hágót, Kelet-Isztriát és Közép-Dalmáciát birtokolhatta volna, és ezen túlmenően a szövetségesek albán területek feletti protektorátusságot, illetve a német gyarmatokból való részesedést is megígérték Olaszországnak. ${ }^{24}$

Fiume - miután a szövetségesek automatikusan Horvátország részeként tekintették a várost - nem került említésre a dokumentumban. Pár hónappal később, 1915.

augusztus 18-án azonban nyélbe ütöttek egy egyezményt, amely Szerbiának ígérte Bosznia, Hercegovina, Szlavónia, Horvátország és Dalmácia mellett - Fiumét is. ${ }^{25}$ Mivel azonban a háborút követően Olaszország egyik fő külpolitikai célja - az afrikai gyarmatbirodalom kiépítésén túl - az adriai, a Duna-menti és a balkáni térség feletti befolyás megszerzése lett, ${ }^{26}$ mindenképpen meg kellett szereznie a kikötővárost, mivel annak birtoklása elengedhetetlennek bizonyult ahhoz, hogy a távlati célok elérésének első lépéseként beltengerévé tehesse az Adriát. ${ }^{27}$

Noha ily módon céljai eléréséhez Olaszországnak égetően szükséges volt Fiume megszerzése, a horvátok önérzetére való tekintettel, illetve gazdasági okokból kifolyólag Jugoszlávia sem mondhatott le a városról. ${ }^{28}$ Fiume hovatartozásának kérdése első ízben 1919. február 18-án merült fel a párizsi békekonferencián, amikor is a jugoszláv képviselők is kifejtették álláspontjukat a kérdésben, és előálltak követeléseikkel. Fiuméval, illetve az egykori Osztrák-Magyar Monarchia délszlávok által lakott, Adria-parti részeivel kapcsolatban Ante Trumbić külügyminiszter foglalta össze a jugoszlávok érveit, amelyek lényege abban állt, hogy Fiume elveszítette volna jelentőségét a hátországa nélkül, amely viszont Horvátországhoz tartozott, és vitathatatlanul délszláv többségü terület volt. ${ }^{29}$

Az olasz delegátusok ezzel szemben a már említett nemzeti önrendelkezési joggal érveltek, így a felek nem jutottak dülőre a kérdést illetően. Ezért az érintettek úgy

\footnotetext{
${ }^{24}$ I documenti diplomatici italiani. Serie 5. Volume 3. A cura di Rodolfo Mosca. Libreria dello Stato. Roma. 470. irat. A londoni titkos szerződés szövege, 1915. április 26.

${ }^{25}$ L. Nagy Zsuzsa 1965, 35.

${ }^{26}$ L. Nagy Zsuzsa 1965, 257.

${ }^{27}$ Hornyák Árpád 2004, 27.

${ }^{28}$ Hornyák Árpád 2004, uo.

${ }^{29}$ Papers relating to the foreign relations of the United States, 1919. The Paris Peace Conference. Volume III. Government Printing Office. Washington. 50-51.
} 
döntöttek, hogy Wilsonra bízzák a probléma megoldását és az igazságtételt, ${ }^{30}$ akit az angolok és a franciák hivatalosan is felkértek a döntőbíráskodásra. ${ }^{31}$ Erre április 19-én került sor, s miután Wilson - aki elvböl ellenezte a titkos szerződéseket - egy olasz protektorátus alatt álló szabad kikötő létrehozását tartotta volna a legigazságosabb megoldásnak, a vita rendkívüli módon elfajult, és az olasz delegátusok kivonultak a békekonferenciáról. ${ }^{32}$

A visszavonulást az olasz politikusok csak jelzésnek szánták, s amint a delegáció egyik tagja, Silvio Crespi is írta naplójában, a végleges távozás nem állt szándékukban, ${ }^{33}$ és Orlando május elején visszautazott Párizsba. Mivel a kérdést illetően ez az intermezzo nem eredményezett megoldást, a miniszterelnök június 19-én lemondott posztjáról, és utóda a jóval mérsékeltebb, kompromisszumra hajlóbb Francesco Saverio Nitti lett, a külügyminisztériumi tárcát pedig Tommaso Tittoni foglalhatta el. Nitti elismerte, hogy Fiumét a londoni szerződés aláírásakor a nagyhatalmak Horvátország részeként tekintették. Úgy vélte, hogy mindjárt a háborúba való belépéskor kellett volna Olaszországnak követelnie a várost, de mivel ezt nem tette meg, az egyetlen, mindenki számára elfogadható megoldás szabadállam létrehozása lett volna. ${ }^{34}$

Mielőtt akár a Nitti által javasolt megoldásra, akár a konfliktus más módon történő rendezésére sor kerülhetett volna, Gabriele D’Annunzio költő és újságíró szabadcsapataival 1919. szeptember 12-én foglalta el Fiume városát („Marcia su Fiume”). Az ötlet, hogy Fiumét „fel kell szabadítani” a szövetséges uralom alól, 1919 tavaszán merült fel, és az olasz politikai elit is támogatta a város katonai megszállását, de nyilvánvalóan nem D’Annunzio parancsnoksága alatt. ${ }^{35}$ A békekonferencián ülésezők szeptember 15-én értesültek a város elfoglalásáról, ${ }^{36}$ és rögvest latolgatni kezdték, hogy miként rendezhetnék a kérdést. Noha D’Annunzio nem ismerte el a Nittikormányt, végcélja kétségtelenül az Olaszországhoz való csatlakozás volt, amit alátámaszt egy beszéde is: „Marconi [a rádió feltalálója - H. P.] hajójáról (...) Fiume eltökélt népe és a meggyötört város védöserege világgá kiáltja, hogy tántorithatatlan elhatározással örökké ki fog tartani az olasz anyaország mellett. "37

Mindeközben Olaszország folyamatosan dolgozott azon, hogy minél előbb megszülessen a lehető legkedvezőbb megoldás a Fiume-kérdésben. 1920. június 15-én Olaszországban ismét kormányváltás történt, Nitti helyét Giovanni Giolitti, a külügyminiszteri posztot pedig Carlo Sforza vette át. Az új kormány - a többi antantállammal egyetértésben - sürgette az olasz-jugoszláv konfliktus rendezését, ezért hosszas tárgyalásokat követően, 1920. november 12-én sor került a rapallói szerződés aláírására. Ennek értelmében létrejött Fiume Szabadállam, amelynek élére a korábbi polgármester, Riccardo Zanella került. Mivel D’Annunzio nem volt hajlandó beletörődni az események alakulásába, december 24-én polgárháború tört ki, ahol az

\footnotetext{
${ }^{30}$ Az Est, 1919. február 18.

${ }^{31}$ Az Est, 1919. március 9.

${ }^{32}$ Burgwyn, Henry James 1997, 10.

${ }^{33}$ Crespi, Silvio 1938, 465. Crespi naplója szerint az olasz delegációs tagok úgy döntöttek, hogy Crespinek Párizsban kell maradnia, míg Orlando és Sonnino visszatérnek. Így a visszatérés elöre eldöntött ténynek tekinthetö.

${ }^{34}$ Nitti, Francesco Saverio 1923, 64.

${ }^{35}$ Ledeen, Michael A. 1975, 70-72.

${ }^{36}$ Papers relating to the foreign relations of the United States, 1919. The Paris Peace Conference. Volume VIII. Government Printing Office. Washington. 225.

${ }^{37}$ Az Est, 1920. október 6.
} 
olasz reguláris hadsereg és a légiósok csaptak össze egymással. ${ }^{38}$ Az időpont végett a polgárháború a „Natale di Sangue” [Véres karácsony - H. P.] elnevezést kapta.

„Fiumét eladták. Kikötőjét az ellenség szerezte meg. "39 - nyilatkozta beszédében D’Annunzio, akit a reguláris hadsereg hamar legyőzött, olyan értelemben, hogy körül zárta a várost, így a Legione Fiume önkéntesei nem juthattak hozzá a létfenntartáshoz szükséges élelemhez. D’Annunzio csapata ezért hamar megadta magát, és a költőnek 1921. január 18-án el kellett hagynia Fiumét. ${ }^{40}$ A Szabadállam 1924 januárjáig állt fenn, amikor is Mussolininak a római egyezmény aláírásával sikerült megegyeznie Jugoszláviával, és Olaszország annektálhatta a területet, melyet végül a második világháborúban veszített el az Isztriával együtt.

Mindennek fényében elmondható, hogy 1918. november 4-ének fiumei történései kiválóan példázzák, hogy egyetlen nap, sőt, néhány perc - esetünkben a nevezetes petíció átadása - milyen mélyreható folyamatokat indíthat el a történelemben. Ez az egy nap évekig tartó konfliktussorozatot eredményezett Olaszország és Jugoszlávia között, s az olaszok sértve érezték magukat amiatt, hogy „győzelmüket megcsonkították” a békekonferencián. E sértettség pedig jelentősen hozzájárult ahhoz, hogy 1922-ben Olaszországban hatalomra jusson Benito Mussolini, és az általa vezetett Nemzeti Fasiszta Párt, amely ugyancsak fontos olasz városként tartotta számon Fiumét.

\section{Felhasznált irodalom}

Ablonczy Balázs 2011, A kikötő alkonya. Fiumei magyarok a két világháború között. In: Ablonczy Balázs: Nyombiztosítás - Letűnt magyarok: kisebbség- és müvelödéstörténeti tanulmányok. Pozsony: Kalligram Kiadó.

Az Est

Az Újság

Burgwyn, Henry James 1997, Italian Foreign Policy in the Interwar Period: 1918-1940. Praeger. London.

Crespi, Silvio 1938, Alla difesa d'Italia in guerra e a Versailles (Diario 1917-1919). Milano.

De Felice, Renzo 1978, D’Annunzio politico: 1918-1938. Editore Laterza. Bari.

Ezer év törvényei. http://www.1000ev.hu/index.php?a=3\&param=5352 (Utolsó letöltés: 2018. június 26.)

Gerini, Giuseppe 1938, Omaggio a Gabriele D'Annunzio:Gabriele D’Annunzio e la passione di Fiume. Editore Termini. Fiume.

Gulyás László-Bali Lóránt 2011, The Fiume question 1918-1920. Öt Kontinens. 2011/1. szám, ELTE. Budapest. 143-150. old.

Gulyás László-Bali Lóránt 2012/b, Ten years from the history of Fiume, 1914-1924. The Twentieth Century. 2012/2. 41-53. old.

Gulyás László-Szávai Ferenc 2018, Közép-Európa és Wilson 14 pontja. BBC History 2018/október 46-51. old.

Hornyák Árpád 2004, Magyar-jugoszláv diplomáciai kapcsolatok: 1918-1927. Újvidék: Forum Könyvkiadó.

\footnotetext{
${ }^{38}$ Valeri, Nino 1963, 27.

${ }^{39}$ De Felice, Renzo 1978, 431.

${ }^{40}$ Volpe, Gioacchino 1981, 114.
} 
I documenti diplomatici italiani. Serie 5. Volume 3. A cura di Rodolfo Mosca. Libreria dello Stato. Roma.

I documenti diplomatici italiani. Serie 6. Volume 1. A cura di Rodolfo Mosca. Libreria dello Stato. Roma.

L. Nagy Zsuzsa 1965, A párizsi békekonferencia és Magyarország 1918-1919. Budapest: Kossuth Kiadó.

L. Nagy Zsuzsa 1965, Az olasz érdekek és Magyarország 1918-1919-ben. In: Történelmi Szemle, 1965. (8. évf.) 2-3. sz.

Ledeen, Michael A. 1975, D’Annunzio a Fiume. Editore Laterza. Roma-Bari.

Macmillan, Margaret 2005, Béketeremtők: az 1919-es párizsi békekonferencia. (Ford.: Barna Judit) Budapest: Gabo Kiadó.

Mák Ferenc 2010, A Szent Korona legszebb gyöngye. In: Domonkos László: A kicserélt város. Budapest: Unicus Kiadó.

Nitti, Francesco Saverio 1923, Nincs béke Európában. Budapest: Pallas Kidó.

Papers relating to the foreign relations of the United States, 1919. The Paris Peace Conference. Volume III. és VIII. Government Printing Office. Washington.

Romsics Ignác 2010, Magyarország története a XX. században. Budapest: Osiris Kiadó. 23. old.

Sonnino, Sidney 1972, Diario 1916-1922. Volume terzo. A cura di Pietro Pastorelli. Editore Laterza. Bari.

Valeri, Nino 1963, D’Annunzio davanti al fascismo. Con documenti inediti. Editore Le Monnier. Firenze.

Volpe, Gioacchino 1981, Gabriele D'Annunzio: l'italiano, il politico, il combattante. Roma. 